\title{
Detection of Streptococcus mutans by PCR amplification of spaP gene
}

\author{
T. ONO, K. HIROTA, K. NEMOTO, E. J. FERNANDEZ, F. OTA* and K. FUKUI \\ Department of Oral Microbiology and Immunology, School of Dentistry and * Department of Food Microbiology, \\ School of Medicine, University of Tokushima, 3-18-15 Kuramoto, Tokushima, Japan
}

\begin{abstract}
Summary. Synthetic oligonucleotide primers were used in the polymerase chain reaction (PCR) to amplify a sequence of the spaP gene, which encodes the surface protein antigen I/II of Streptococcus mutans. A DNA fragment of $c .192 \mathrm{bp}$ was amplified from lysed S. mutans cells or isolated DNA. With $S$. mutans cells, the lower limit of detection was $4-40 \mathrm{cfu}$. With these primers, 13 reference and 50 clinical strains of $S$. mutans were identified. Amplification of the 192-bp product was not demonstrated when 41 strains of other streptococcal and nonstreptococcal species were tested. The spaP gene PCR has potential for the rapid diagnosis of S. mutans infections.
\end{abstract}

\section{Introduction}

Viridans streptococci are the most common cause of bacterial endocarditis. ${ }^{1-3}$ Streptococcus mutans, a member of the viridans group of streptococci, is recognised as part of the normal oral flora of man, and is an aetiological agent in smooth-surface dental caries., In experimental animals, induction of bacteraemia has been demonstrated following dental extraction ${ }^{6,7}$ and, generally, diagnosis depends on the isolation of the bacterium from the infection site or blood. DNA probes to $g t f B$ and $f t f$ genes for glucosyltransferase and fructosyltransferase, respectively, have been reported for the detection of $S$. mutans, ${ }^{8}$ but these probes are not sensitive.

PCR procedures for the amplification of streptococcal and enterococcal genes have been reported, ${ }^{9,10}$ but there has been no report of PCR of a specific gene fragment for the identification of $S$. mutans. $S$. mutans strains produce surface protein antigen I/II (Ag I/II) and this may facilitate their ability to colonise sites. ${ }^{11,12}$ The gene encoding $\mathrm{Ag}$ I/II, spaP or pac, has been cloned from two strains of serotype $c$ and one strain of serotype $f$ of $S$. mutans, ${ }^{13-15}$ and although similar antigens have been found in other streptococci, it is likely that species-specific regions exist in the spaP gene. ${ }^{16-18}$ The purpose of this study was to utilise the unique DNA sequence for $\mathrm{Ag}$ I/II to amplify the spaP gene by PCR.

\section{Materials and methods}

\section{Bacterial strains and culture conditions}

The 13 reference strains of $S$. mutans used in this study are listed in table I. Fifty clinical strains were isolated from the dental plaque of students (18-20 years old) and identified by biochemical tests including API-20 Strep system and API-Zym (bioMérieux, La Balme des Grottes, France) and iminunological reactions between whole cells and antiserum or monoclonal antibodies. ${ }^{19}$ Other oral streptococci and nonstreptococcal strains are listed in table II. All strains were grown in brain heart infusion broth (BHI). $S$. mutans strain B56 was grown at $37^{\circ} \mathrm{C}$ for $24 \mathrm{~h}$ in BHI supplemented with sucrose $5 \%$ for injection into mice.

\section{DNA preparation}

Chromosomal DNA was purified from the Ingbritt strain of $S$. mutans by the method reported by Okahashi et al. ${ }^{13}$

\section{Oligonucleotide probes}

Primers were selected on the basis of the spaP gene from $S$. mutans strain NG5. ${ }^{17}$ The sequences of the two primers were 5'-AACGACCGCTCTTCAGCAGATACC-3' (sense primer) and 5'-AGAAAGAACATCTCTAATTTCTTG-3' (anti-sense primer).

\section{Preparation of bacteria for PCR}

Bacterial cells were harvested by centrifugation. The 


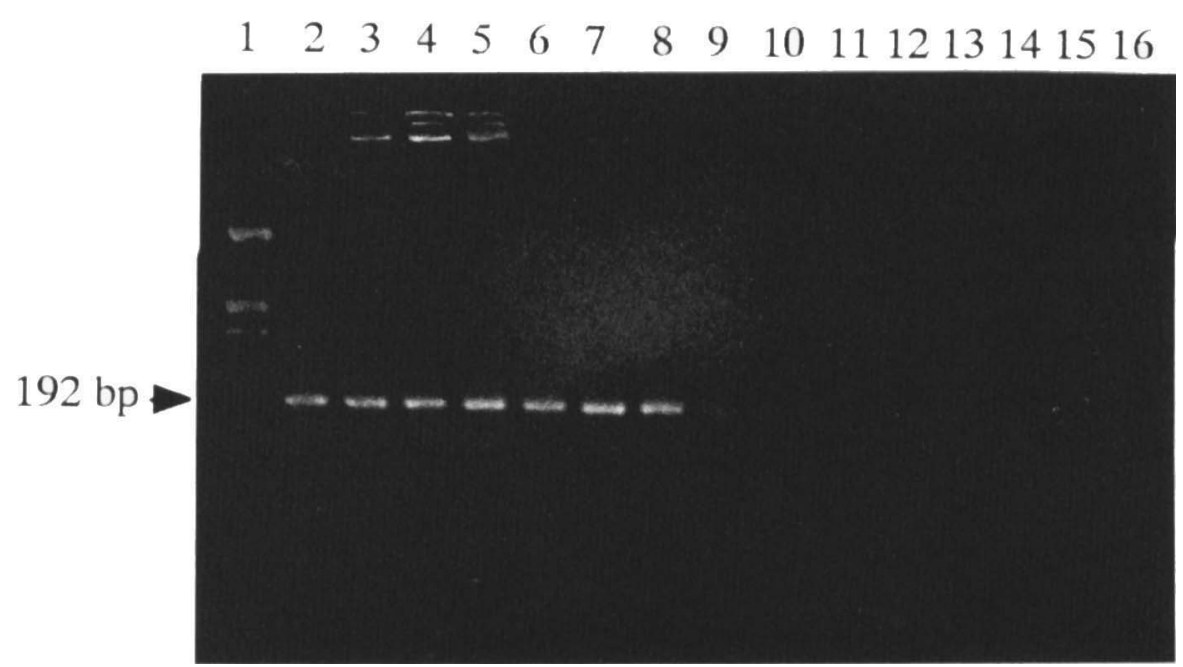

Fig. 1. PCR amplification of spaP gene from cell lysates of S. mutans, S. sobrinus and S. sanguis. Lane 1, molecular mass markers of pUC119 Hinf I digests; 2-8, S. mutans Ingbritt, MT6R, NCTC10449, LM7, MT703R, SE11, OMZ175, respectively; 9-14, S. sobrinus MT615R, OMZ176, B13, OMZ65, 6715, K1R, respectively; 15-16, S. sanguis ST6, ATCC10556. $\$$, 192-bp products.

cell pellet was resuspended in $100 \mathrm{ml}$ of sucrose $20 \%$ $\mathrm{w} / \mathrm{v}$ in STE $(10 \mathrm{~mm}$ Tris- $\mathrm{HCl}, \mathrm{pH} 8.0 ; 100 \mathrm{mM} \mathrm{NaCl}$; $1 \mathrm{~mm}$ EDTA, pH 8.0) containing lysozyme $(6 \times$ crystallised, Seikagaku Kogyo Co., Tokyo) $0.5 \mathrm{mg} / \mathrm{ml}$ and $N$-acetylmuramidase (Seikagaku Kogyo Co.) $0.1 \mathrm{mg} / \mathrm{ml}$. After incubation at $37^{\circ} \mathrm{C}$ for $60 \mathrm{~min}$, samples were centrifuged and the pellets were resuspended in $100 \mathrm{ml}$ of lysis buffer consisting of $50 \mathrm{mM}$ $\mathrm{KCl}, 10 \mathrm{~mm}$ Tris- $\mathrm{HCl}$, pH 8.3, gelatin $0 \cdot 1 \mathrm{mg} / \mathrm{ml}$, Nonidet P-40, $0.45 \%$ and Tween $20,0.45 \%$, together with $80 \mathrm{mg}$ of proteinase $\mathrm{K}$. After incubation at $60^{\circ} \mathrm{C}$ for $60 \mathrm{~min}$, the samples were heated at $100^{\circ} \mathrm{C}$ for $5 \mathrm{~min}$ to inactivate proteinase $\mathrm{K}$, residual cellular proteinases or nucleases, and to denature the target DNA.

For PCR amplification of $S$. mutans cultured in vitro in simulated clinical specimens, $2-\left(2 \times 10^{4}\right) \mathrm{cfu}$ of $S$. mutans cells were added to $10 \mathrm{ml}$ of culture-negative blood and diluted in $1 \mathrm{ml}$ of TE buffer ( $10 \mathrm{mM}$ Tris$\mathrm{HCl}, \mathrm{pH} 8 \cdot 0,1 \mathrm{~mm}$ EDTA). Pellets of cells were made by centrifugation at $13000 \mathrm{~g}$ for $15 \mathrm{~min}$, washed three times with the same buffer, and resuspended in the lysis buffer described above. Blood samples from mice challenged with $S$. mutans were treated in the same manner.

\section{PCR amplification}

Amplification was performed in a thermal cycler (IWAKI TSR-300, Tokyo) with a recombinant Taq DNA polymerase (Wako Junyaku, Osaka). The reaction mixture consisted of $1-4 \mathrm{ml}$ of lysate, $2 \mathrm{ml}$ of $10 \times$ PCR amplification buffer $(100 \mathrm{~mm}$ Tris- $\mathrm{HCl}$, $500 \mathrm{~mm} \mathrm{KCl}, 15 \mathrm{~mm} \mathrm{MgCl}_{2}$, Triton X-100, $1 \%$ ), $0.5 \mathrm{ml}$ of sense and anti-sense primers (20 mM, Daiichi Kikai, Tokushima, Japan) and $0.5 \mathrm{ml}$ of Taq polymerase $(1.25 \mathrm{u} / \mathrm{ml}$; Wako Junyaku, Osaka) and was adjusted to $20 \mathrm{ml}$ by the addition of distilled water. Mineral oil was also added to the mixtures to prevent evaporation. In all, 37 cycles were run under the following conditions: DNA denaturation at $94^{\circ} \mathrm{C}$ for $30 \mathrm{~s}$, primer annealing at $48^{\circ} \mathrm{C}$ for $1 \mathrm{~min}$, and DNA extension at $74^{\circ} \mathrm{C}$ for $30 \mathrm{~s}$. After the final cycle the reaction was terminated at $74^{\circ} \mathrm{C}$ for $2 \mathrm{~min}$.

\section{Agarose gel electrophoresis}

The PCR amplification products were analysed by agarose gel electrophoresis in agarose (NuSieve $3: 1$, FMC, USA) $2.5 \%$ gels with ethidium bromide $0.5 \mathrm{mg} / \mathrm{ml}$ in TAE $(0.04 \mathrm{M}$ Tris-acetate, $1 \mathrm{~mm}$ EDTA, $\mathrm{pH} 8 \cdot 0)$.

\section{Enzyme immunoassay (EIA)}

EIA was done according to procedures described previously. ${ }^{20}$ Monoclonal antibodies, MAb498 and MAb516 against $\mathrm{Ag} \mathrm{I/II} \mathrm{were} \mathrm{used.}{ }^{19}$

\section{Preparation of blood samples}

Three male ddY mice weighing 30-40 g were given $0.1 \mathrm{ml}$ of $S$. mutans strain B56 cell suspension in phosphate-buffered saline $\left(5 \times 10^{7} \mathrm{cfu}\right)$ by injection into the tail vein. After injection, blood samples were collected at $5 \mathrm{~min}, 30 \mathrm{~min}, 24 \mathrm{~h}$ and $72 \mathrm{~h}$.

\section{Results}

The primer set synthesised for this study allowed the PCR amplification of a gene fragment of $S$. mutans strains after 37 cycles. Results obtained by PCR with reference strains of $S$. mutans, $S$. sobrinus and $S$. sanguis and reactivity with two MAbs specific for $\mathrm{Ag}$ I/II are shown in fig. 1. Only the $S$. mutans strains gave an amplification product (table I and fig. 1); this appeared as a single DNA band of c. $192 \mathrm{bp}$. In contrast to MAb498, which reacted with both $S$. mutans and $S$. sobrinus, the PCR primer set resulted in a PCR product from $S$. mutans cell lysates only. MAb516 specific for $S$. mutans serotype $c$ strains did not react with MT6R (serotype $c$ ), whereas DNA from 
Table I. Reactivity of reference strains of mutans streptococci with monoclonal antibodies and PCR positivity of a spaP gene fragment

\begin{tabular}{|c|c|c|c|c|}
\hline \multirow{2}{*}{ Species } & \multirow{2}{*}{ Strains } & \multicolumn{2}{|c|}{ EIA reactivity with* } & \multirow{2}{*}{$\begin{array}{c}\text { PCR } \\
\text { with spaP }\end{array}$} \\
\hline & & MAb498 & MAb516 & \\
\hline \multirow[t]{13}{*}{ S. mutans } & Ingbritt & + & + & + \\
\hline & MT6R & + & - & + \\
\hline & K302 & + & + & + \\
\hline & $\mathrm{T} 282$ & + & + & + \\
\hline & B56 & + & + & + \\
\hline & NCTC 10449 & + & + & + \\
\hline & LM7 & + & - & + \\
\hline & P4 & + & - & + \\
\hline & MT703R & + & - & + \\
\hline & SE11 & + & - & + \\
\hline & MT557 & - & - & + \\
\hline & OMZ175 & + & - & + \\
\hline & 161 & - & - & + \\
\hline \multirow[t]{8}{*}{ S. sobrinus } & OMZ176 & + & - & - \\
\hline & MT615R & + & - & - \\
\hline & $\mathrm{B} 13$ & + & - & - \\
\hline & OMZ65 & + & - & - \\
\hline & 6715 & + & - & - \\
\hline & K1R & + & - & - \\
\hline & $\mathrm{TH} 21$ & + & - & - \\
\hline & SL1 & + & - & - \\
\hline S. cricetus & HS1 & - & - & - \\
\hline S. rattus & FAl & - & - & - \\
\hline S. downei & MF25 & - & - & - \\
\hline
\end{tabular}

* Reactivity of NCTC10449 was taken as $100 \%$ and the positive values were $>50 \%$.

this strain was successfully amplified. DNA from strains MT557 and 161, which did not react with MAb 498, were also amplified. Therefore, the primer set can be used for PCR amplification of the spaP gene 192-bp fragment even when $\mathrm{Ag} \mathrm{I} / \mathrm{II}$ is not expressed on the cell surface.

\section{Sensitivity}

The minimum level for detection of $S$. mutans bacterial cells or isolated DNA by PCR product was
Table II. Reactions of reference strains of other oral streptococcal and various non-streptococcal bacteria by PCR for amplification of a spaP gene fragment

\begin{tabular}{|c|c|c|}
\hline Species & Strains & $\begin{array}{l}\text { PCR } \\
\text { result }\end{array}$ \\
\hline \multirow[t]{3}{*}{ S. sanguis } & ATCC 10556 & - \\
\hline & KPE2 & - \\
\hline & ST6 & - \\
\hline \multirow[t]{2}{*}{ S. salivarius } & M36 & - \\
\hline & NCTC8618 & - \\
\hline \multirow[t]{2}{*}{ S. oralis } & ATCC9811 & - \\
\hline & ATCC10557 & - \\
\hline \multirow[t]{3}{*}{ S. gordonii } & M5 & - \\
\hline & Charllis & - \\
\hline & NCTC10231 & - \\
\hline \multirow[t]{2}{*}{ S. ferus } & $8 \mathrm{Sl}$ & - \\
\hline & HD3 & - \\
\hline S. pyogenes & A374 & - \\
\hline Staphylococcus aureus & 209P & - \\
\hline \multirow[t]{2}{*}{ Lactobacillus plantanum } & ATCC8014 & - \\
\hline & ATCC4646 & - \\
\hline $\begin{array}{l}\text { Actinobacillus } \\
\text { actinomycetemcomitans }\end{array}$ & Y4 & - \\
\hline Eikenella corrodens & 1073 & - \\
\hline Porphyromonas gingivalis & 381 & - \\
\hline Propionibacterium acnes & 11827 & - \\
\hline Candida albicans & IFO1060 & - \\
\hline
\end{tabular}

examined. A cell suspension of $S$. mutans Ingbritt was diluted serially in saline to $4-\left(4 \times 10^{6}\right) \mathrm{cfu} / \mathrm{ml}$. The detection limits ranged from 4 to $40 \mathrm{cfu}$ (fig. 2A). DNA from $S$. mutans Ingbritt was isolated, serially diluted in distilled water, and used as a template. The results showed that $0.3 \mathrm{pg}$ of $S$. mutans DNA in the reaction mixture was the minimum needed to obtain a detectable PCR product (fig. 2B).

\section{Specificity}

Thirteen reference strains of $S$. mutans and 24 reference strains of other streptococci were used as templates for the primers with $1 \times 10^{4}$ bacterial cells in
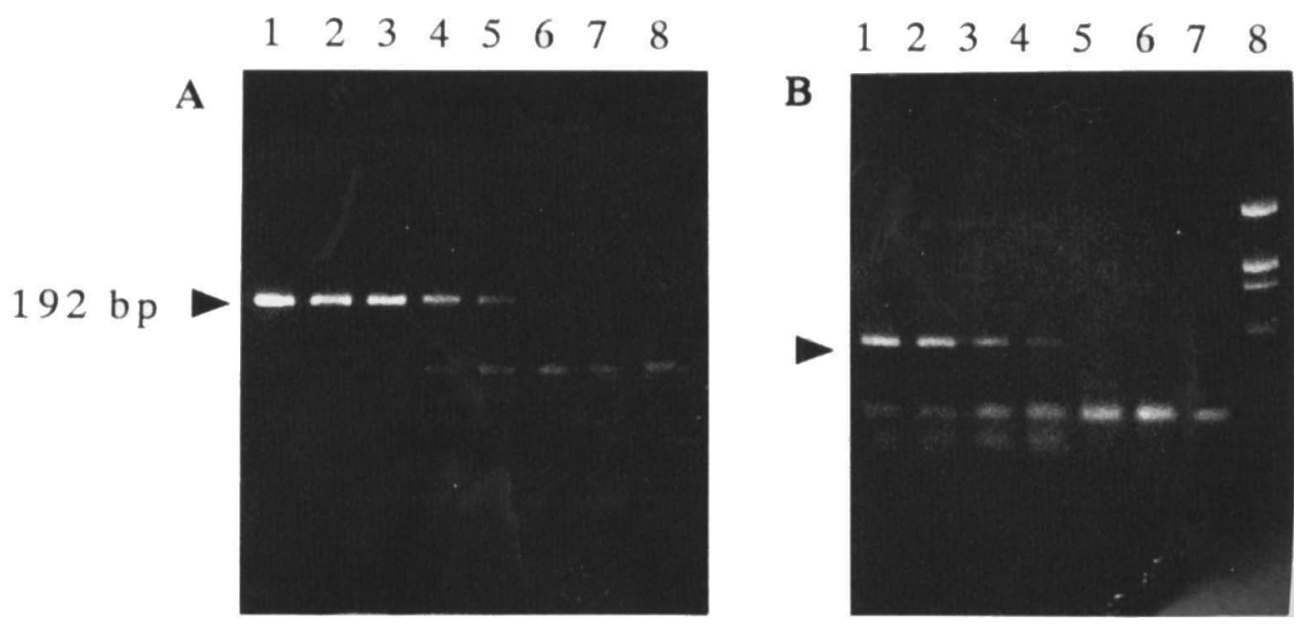

Fig. 2. PCR products amplified from serial dilutions of A, S. mutans Ingbritt and S. sobrinus SL1 cells and B, purified S. mutans DNÁ. A : lanes 1-7, cfu of $S$. mutans Ingbritt are $4 \times 10^{6}, 4 \times 10^{4}, 4 \times 10^{3}, 4 \times 10^{2}, 4 \times 10,4,0$, respectively; 8 , S. sobrinus SLI $4 \times 10^{6}$ cfu. B: lanes 1-7, the DNA contents are $300,30,3,0 \cdot 3,0 \cdot 03,0.003 \mathrm{pg}$, respectively $; 8$, molecular mass markers are pUC119 Hinf I digests. $\$$, 192-bp products. The bands appearing at $c .50 \mathrm{bp}$ are primer-dimers. 


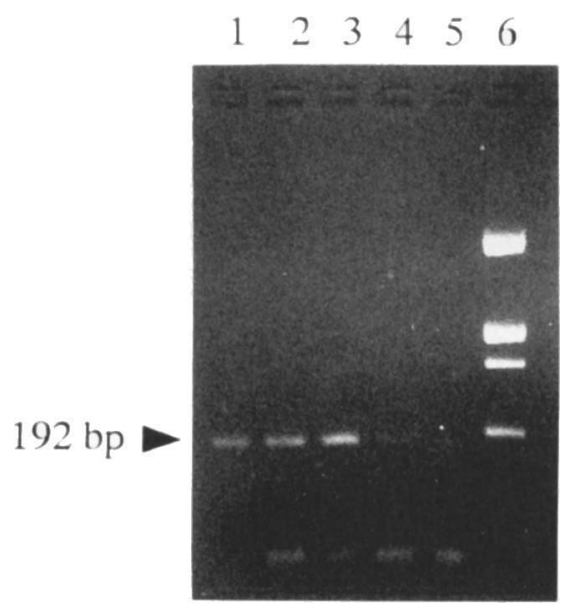

Fig. 3. PCR products generated with $S$. mutans Ingbritt cells in culture-negative whole blood. Lanes: 1-5, cfu are $2 \times 10^{4}, 2 \times 10^{2}, 2$, 0 , respectively; 6, molecular mass markers. $>, 192-b p$ PCR products.

the PCR mixture. All strains of $S$. mutans yielded amplification product, unlike the other streptococci examined (tables I, II and fig. 1). The specificity of the primer set was also examined by testing 50 isolates of $S$. mutans and nine of $S$. sobrinus. With all the $S$. mutans isolates, a PCR product of $c .192 \mathrm{bp}$ was generated. None of the other species tested gave an amplification product (table II), demonstrating that the 192-bp gene fragment amplified by PCR with the primer set was specific for $S$. mutans strains.

\section{PCR of blood samples}

Culture-negative whole blood was tested with and without the addition of $S$. mutans strain B56 cells cultured in vitro (fig. 3 ). Samples containing 200 cells of $S$. mutans were positive by PCR. In experimental mice challenged with $S$. mutans cells, PCR products were generated from bacteria in the blood (fig. 3) when the viable cells were $19.2 \%$ and $3.3 \%$ of the original cell number at $30 \mathrm{~min}$ and $24 \mathrm{~h}$ after injection (data not shown). After 3 days, a positive PCR result was also obtained when the viable cell count was $<100 \mathrm{cfu} / \mathrm{ml}$.

\section{Discussion}

Results show that the detection of $S$. mutans by PCR with the spaP gene is more sensitive than when using the $g t f B$ and $f t f$ gene probes $;^{8}$ the sensitivity of the latter is $10^{4} \mathrm{cfu}$ less. Furthermore, the present method is simpler and more suitable for routine use than the methods employing Southern hybridisation ${ }^{8}$ for the rapid and accurate diagnosis of $S$. mutans infections.

Viridans streptococci are the most frequently isolated bacteria from cases of bacterial endocarditis resulting from dental extraction and it has been reported that $S$. sanguis and $S$. mutans are the most frequent isolates from the bloodstream of endocarditis patients. $^{3,21}$ However, there is a need for studies with up-to-date protocols to identify the causative species and to enable more precise studies of the pathogenic mechanisms involved in endocarditis. Also, because $S$. mutans is resistant to host clearance mechanisms, having been detected in blood up to 3 days after the injection of these streptococci, it would be useful to clarify the mechanism of colonisation of the surfaces of heart valves and kidneys.

Recently, it has been reported that $S$. sanguis, $S$. oralis and $S$. gordonii have been isolated frequently from cases of endocarditis, ${ }^{22}$ but the identity of the causative organisms remains unclear because identification was based on biochemical methods and, therefore, difficult to compare with previous reports. The PCR identification strategy used in this study could more accurately identify strains of $S$. mutans than in previous studies and also heralds the development of a PCR method for the identification of $S$. sanguis and other species of oral viridans streptococci.

We thank Dr S. Hamada, Department of Oral Bacteriology, Osaka University, Dr R. A. Whiley, Department of Oral Micro-

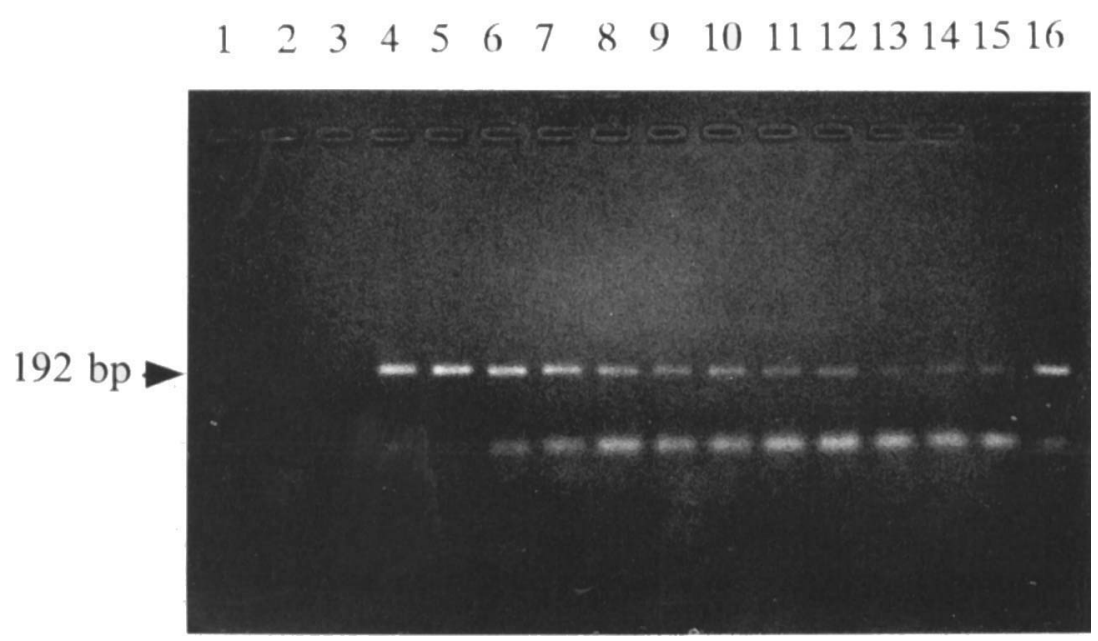

Fig. 4. PCR products generated by direct testing of blood from mice infected with $S$. mutans. Lanes 1-3, before bacterial injection, 4-6, 5 mins ; 7-8, $30 \mathrm{~min} ; \mathbf{9 - 1 2}, 24 \mathrm{~h} ; \mathbf{1 3 - 1 5}, 72 \mathrm{~h}$ after injection, respectively; 16, $S$. mutans Ingbritt $2 \times 10^{4}$ cfu., 192 -bp PCR products. 
biology, London Hospital Medical College, London, U.K., and Dr R. Nakamura, Department of Preventive Dentistry, University of Tokushima, Tokushima, Japan, for providing many of the strains used in this study.

\section{References}

1. Dall L, Barnes WG, Lane JW, Mills J. Enzymatic modification of glycocalyx in the treatment of experimental endocarditis due to viridans streptococci. $J$ Infect Dis 1987; 156: 736-740.

2. Munro CL, Macrina FL. Sucrose-derived exopolysaccharides of Streptococcus mutans V403 contribute to infectivity in endocarditis. Mol Microbiol 1993; 8: 133-142.

3. Knox KW, Hunter $\mathrm{N}$. The role of oral bacteria in the pathogenesis of infective endocarditis. Aust Dent J 1991; 36: 286-292.

4. Hamada S, Slade HD. Biology, immunology, and cariogenicity of Streptococcus mutans. Microbiol Rev 1980; 44: 331-384.

5. Loesche WJ. Role of Streptococcus mutans in human dental decay. Microbiol Rev 1986; 50: 353-380.

6. Overholser CD, Moreillon P, Glauser MP. Experimental bacterial endocarditis after dental extractions in rats with periodontitis. $J$ Infect Dis 1987 ; 155: 107-112.

7. Moreillon P, Overholser CD, Malinverni R, Bille J, Glauser MP. Predictors of endocarditis in isolates from cultures of blood following dental extractions in rats with periodontal disease. J Infect Dist 1988; 157: 990-995.

8. Smorawinska M, Kuramitsu HK. DNA probes for detection of cariogenic Streptococcus mutans. Oral Microbiol Immunol 1992; 7: 177-181.

9. Hynes WL, Ferretti JJ, Gilmore MS, Segarra RA. PCR amplification of streptococcal DNA using crude cell lysates. FEMS Microbiol Lett 1992; 94 : 139-142.

10. Quivey RG, Faustoferri RC. In-vivo inactivation of the Streptococcus mutans recA gene mediated by PCR amplification and cloning of a recA DNA fragment. Gene 1992; 116: 35-42.

11. Lee SF, Progulske-Fox A, Erdos GW et al. Construction and characterization of isogenic mutants of Streptococcus mutans deficient in major surface protein antigen $\mathrm{Pl}$ (I/II). Infect Immun 1989; 57: 3306-3313.

12. Gibbons RJ, Cohen L, Hay DI. Strains of Streptococcus mutans and Streptococcus sobrinus attach to different pellicle receptors. Infect Immun 1986; 52: 555-561.

13. Okahashi N, Sasakawa C, Yoshikawa M, Hamada S, Koga T. Cloning of a surface protein antigen gene from serotype $c$ Streptococcus mutans. Mol Microbiol 1989; 3: 221-228.

14. Lee SF, Progulske-Fox A, Bleiweis AS. Molecular cloning and expression of a Streptococcus mutans major surface protein antigen, P1 (I/II), in Escherichia coli. Infect Immun 1988; 56: $2114-2119$.

15. Okahashi N, Sasakawa C, Yoshikawa M, Hamada S, Koga T. Molecular characterization of a surface protein antigen gene from serotype $c$ Streptococcus mutans, implicated in dental caries. Mol Microbiol 1989; 3: 673-678.

16. LaPolla RJ, Haron JA, Kelly CG et al. Sequence and structural analysis of surface protein antigen I/II (SpaA) of Streptococcus sobrinus. Infect Immun 1991; 59: 2677-2685.

17. Ma J K-C, Kelly CG, Munro G, Whiley RA, Lehner T. Conservation of the gene encoding streptococcal antigen I/II in oral streptococci. Infect Immun 1991; 59: 2686-2694.

18. Tokuda M, Okahashi N, Takahashi I et al. Complete nucleotide sequence of the gene for a surface protein antigen of Streptococcus sobrinus. Infect Immun 1991; 59: 3309-3312.

19. Fernandez EJ. Streptococcus mutans serotype c-specific determinant in the surface protein antigen I/II. Shikoku Dent Res 1993; 6: 79-91.

20. Hirota K, Ota F, Senesi S et al. A comparison of various EIA plates for the analysis of polysaccharide antigens and serological identification of oral streptococci. Zentralbl Bakteriol 1992; Suppl 22: 116-118.

21. Herzberg MC, Gong K, MacFarlane GD et al. Phenotypic characterization of Streptococcus sanguis virulence factors associated with bacterial endocarditis. Infect Immun. 1990; 58: $515-522$.

22. Douglas CWI, Heath J, Hampton KK, Preston FE. Identity of viridans streptococci isolated from cases of infective endocarditis. J Med Microbiol 1993; 39: 179-182. 